\title{
Preface to the special issue on systemic risk and financial networks
}

\author{
Agostino Capponi ${ }^{1} \cdot$ Robert Jarrow $^{2}$ \\ Published online: 9 January 2021 \\ (c) Springer-Verlag GmbH Germany, part of Springer Nature 2021
}

\section{Preface}

It has been a dozen years since the largest financial crisis hit the global economy after the Great Depression. Since this event, understanding the mechanism underlying the origination, transmission, and mitigation of systemic risk has been a priority for academics, practitioners, and regulators worldwide. This investigation has led to many important research contributions recently surveyed in review articles (e.g. [14,16]).

Despite enormous progress having been made, the topic of systemic risk, along with its implications for the real economy and policy making, remains a subject of active investigation. The continued interest in this topic is manifested by the many conferences, workshops and special events organized each year by central banks and academic institutions on this theme.

Agostino Capponi (Columbia), Robert Jarrow (Cornell), and Ulrich Horst (Humboldt University) have decided to dedicate a special issue to the topic of systemic risk and financial networks. The objective of this issue is to provide an overview of research directions currently being pursued by the community. The hope is to both incite interest in this topic among graduate students and young academic and to provide a platform for discussion among professionals who wish the push forward the frontiers of systemic risk research.

The contributions to this Special Issue touch upon critical issues in the measurement, modeling, and management of systemic risk. They illustrate the various approaches to the problem put forward by theoretical and empirical research, as well as the integration of data methodologies appropriate for this investigation.

Common to many financial crises is the bursting of bubbles. For example, the global 2007-2008 financial crisis was preceded by the bursting of the house price bubble. Jarrow and Lamichhane [17] investigate the theoretical underpinnings of this mechanism in a general equilibrium framework. They show that the interaction of market liquidity, asset price bubbles

Agostino Capponi

ac3827@columbia.edu

Robert Jarrow

raj15@cornell.edu

1 Department of Industrial Engineering and Operations Research, Columbia University, New York, NY 10027, USA

2 Johnson Graduate School of Management, Cornell University, Ithaca, NY 14853, USA 
originated from heterogeneous beliefs and trading constraints, can lead to the non-existence of an equilibrium and thus to the breakdown of the economic system.

One of most significant regulatory response to the 2007-2008 financial crisis was the Dodd-Frank Wall Street Reform and Consumer Protection Act (2010), which mandated the central clearing of all standardized over-the-counter (OTC) derivatives. Academic research has studied the economic drivers of clearinghouse margins [6] and netting benefits offered by centralized trading [11]. Existing stress testing is based on the Cover II principle, according to which CCPs should have enough collateral to cover losses arising when the two largest clearing members default. Paddrik and Young [18] challenge this view, and develop a stress testing framework which accounts for network spillover effects between members and non-members of the clearinghouse. They estimate the clearinghouse default probability accounting both for insolvency and liquidity constraints.

The systemic risk literature has also analyzed the two most prominent channels of financial contagion. The first channel is counterparty risk contagion, and arises when banks fail to repay their liabilities in full to their counterparties [2,12]. The second channel is balance sheet contagion [7,15], and originates from banks' asset commonality and price pressures realized on the assets when banks necessarily liquidate them on a short notice to meet financial constraints. Detering et al. [10] analyze the joint effects of these two channels in a random network model using an asymptotic analysis.

Another important conduit of systemic risk is the sovereign debt market [3]. European debt markets were severely hit by shocks soon after the 2007-2008 financial crisis, raising concerns about the level of sovereign credit risk. These concerns led to rapid increase of sovereign credit spreads as well as to a downgrade of the U.S. Treasury by S\&P. Castellano et al. (2020)'s paper [8] develops an asset allocation model using European sovereign CDS spreads, with the objective of minimizing systemic risk measured in terms of sovereign risk for a set of countries.

The lack of comprehensive data to accurately estimate the network is a major problem in the study of economic and financial networks. This is partly due to interoperability constraints among different jurisdictions, difficulties in collecting and maintaining these datasets, and noise in the recording process. Gandy and Veraart [13] propose a statistical framework to estimate and predict weights in directed networks, with a special focus on interbank credit default swap exposures and cross-border lending between countries.

To guide the design of systemic related capital requirements, it is important to identify axioms that systemic risk measures should satisfy (e.g [9]). Arduca et al. [4] study two types of systemic risk measures: those following the "first allocate, then aggregate" principle, and those following the "first aggregate, then allocate" strategy.

Most studies of financial networks focus on ex-post contagion, i.e., they analyze how a shock hitting a bank triggers distress in the network due to credit relations between banks. It is however well understood that ex-ante considerations also play a role in the dynamics of financial crisis, liquidity evaporation, and financial intermediation. For example, credit freezes induced by the fear that future liquidity or borrower profitability would be compromised were observed during the 2007-2008 crisis [5]. Acemoglu et al. (2020)'s paper [1] examines how fears of potential future default cascades can trigger ex-ante credit freezes, even before the realization of the actual adverse shocks. A contribution of their paper is illustrating how the nature of these credit freezes depend critically on the structure of the underlying financial network. Their study contributes to an understanding of endogenous network formation, a notoriously complex problem for which there exists no "gold standard" framework at present. 
In conclusion, we would like to thank the editor-in-chiefs Ulrich Horst and Frank Riedel of Mathematics and Financial Economics, and the publisher Springer Verlag, for supporting this special issue. We are hopeful that this issue will prompt the broad mathematical and financial economics community to address the still outstanding issues in systemic risk and financial networks.

\section{References}

1. Acemoglu, D., Ozdaglar, A., Siderius, A., Tahbaz-Salehi, J.: Systemic credit freezes in financial lending networks. Math. Financ. Econ. (2020). https://doi.org/10.1007/s11579-020-00272-z

2. Acemoglu, D., Ozdaglar, A., Tahbaz-Salehi, A.: Systemic risk and stability in financial networks. Am. Econ. Rev. 105(2), 564-608 (2015)

3. Ang, A., Longstaff, F.: Systemic sovereign credit risk: lessons from the U.S. and europe. J. Monet. Econ. 60(5), 493-510 (2013)

4. Arduca, M., Koch-Medina, P., Munari, C.: Dual representations for systemic risk measures based on acceptance sets. Math. Financ. Econ. (2019). https://doi.org/10.1007/s11579-019-00250-0

5. Brunnermeier, M.: Deciphering the liquidity and credit crunch 2007-2008. J. Econ. Perspect. 23(1), 77-100 (2009)

6. Capponi, A., Cheng, A.: Clearinghouse margin requirements. Oper. Res. 66(6), 1542-1558 (2018)

7. Capponi, A., Larsson, M.: Price contagion through balance sheet linkages. Rev. Asset Pricing Stud. 5(2), 227-253 (2015)

8. Castellano, R., Cerqueti, R., Clemente, G., Grassi, R.: An optimization model for minimizing systemic risk. Math. Financ. Econ. (2020). https://doi.org/10.1007/s11579-020-00279-6

9. Chen, C., Iyengar, G., Moallemi, C.: An axiomatic approach to systemic risk. Manag. Sci. 56(6), 13731388 (2013)

10. Detering, N., Meyer-Brandis, T., Panagiotou, K., Ritter, D.: An integrated model for fire sales and default contagion. Math. Financ. Econ. (2020). https://doi.org/10.1007/s11579-020-00273-y

11. Duffie, D., Zhu, H.: Does a central clearing counterparty reduce counterparty risk? Rev. Asset Pricing Stud. 1, 74-95 (2011)

12. Eisenberg, L., Noe, T.: Systemic risk in financial systems. Manag. Sci. 47(2), 236-249 (2001)

13. Gandy, A., Veraart, L.: Compound poisson models for weighted networks with applications in finance. Math. Financ. Econ. (2020). https://doi.org/10.1007/s11579-020-00268-9

14. Glasserman, P., Young, H.: Contagion in financial networks. J. Econ. Lit. 54(3), 779-831 (2016)

15. Greenwood, R., Landier, A., Thesmar, A.: Vulnerable banks. J. Financ. Econ. 115(3), 417-485 (2015)

16. Jackson, M., Pernoud, A.: Systemic risk in financial networks: a survey (2020). https://papers.ssrn.com/ sol3/papers.cfm?abstract_id=3651864. Accessed 28 Nov 2020

17. Jarrow, R., Lamichhane, $\bar{S}$.: Asset price bubbles, market liquidity, and systemic risk. Math. Financ. Econ. (2019). https://doi.org/10.1007/s11579-019-00247-9

18. Paddrik, M., Young, P.: How safe are central counterparties in credit default swap markets? Math. Financ. Econ. (2020). https://doi.org/10.1007/s11579-019-00243-z

Publisher's Note Springer Nature remains neutral with regard to jurisdictional claims in published maps and institutional affiliations. 